\title{
MENENGAHI POLEMIK RENCANA INVESTASI BPKH PADA TANAH WAKAF BAITUL ASYI
}

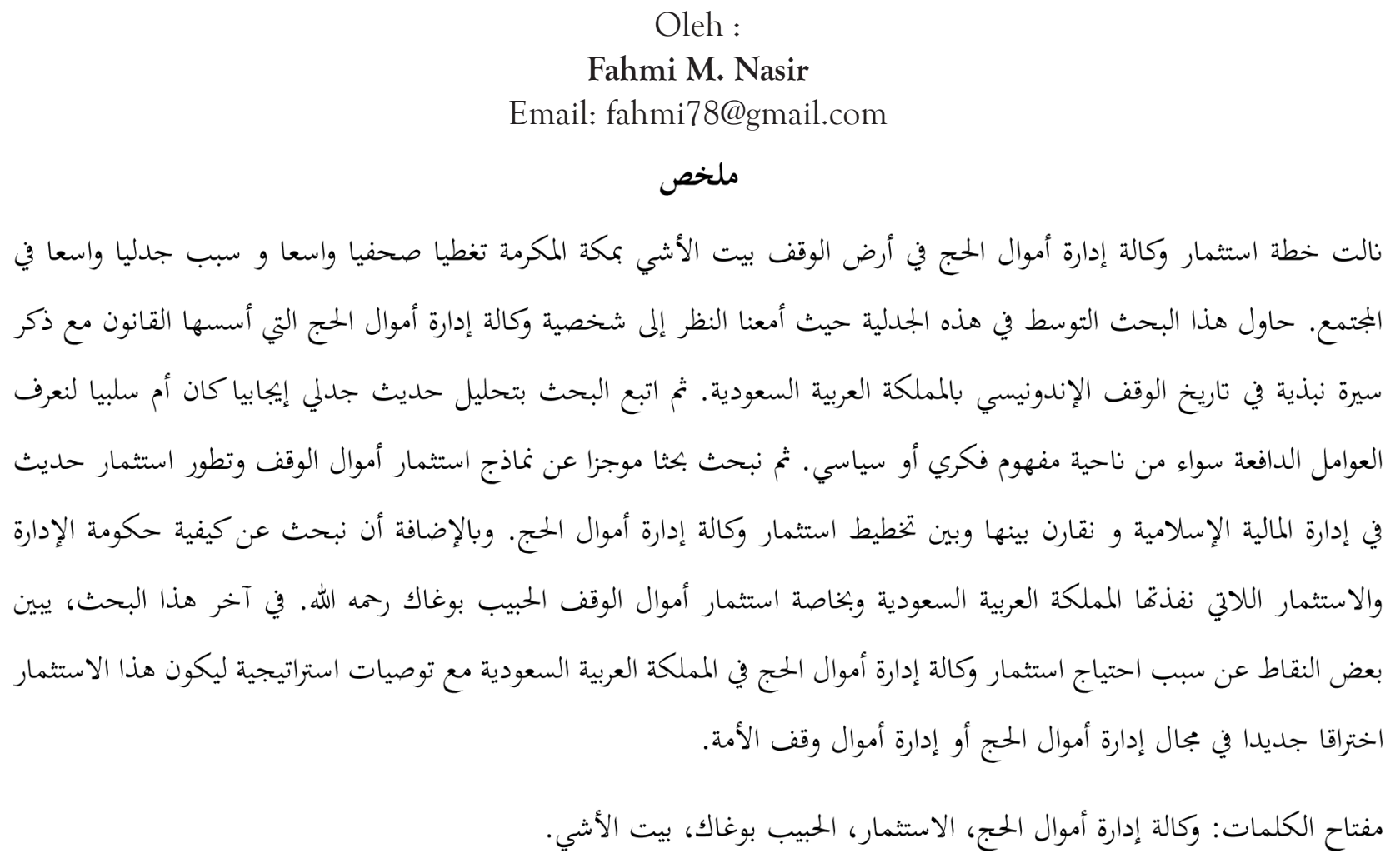

Fahmi M. Nasir

Email: fahmi78@gmail.com

$$
\begin{aligned}
& \text { نالت خطة استثمار وكالة إدارة أموال الحج في أرض الوقف بيت الأشي بمكة المكرمة تغطيا صحفيا واسعا و سبب جدليا واسعا في } \\
& \text { الجتمع. حاول هذا البحث التوسط في هذه الجدلية حيث أمعنا النظر إلى شخصية وكالة إدارة أموال الحج التي أسسها القانون مع ذكر } \\
& \text { سيرة نبذية في تاريخ الوقف الإندونيسي بالمملكة العربية السعودية. ثم اتبع البحث بتحليل حديث جدلي إيجابيا كان أم سلبيا لنعرف } \\
& \text { العوامل الدافعة سواء من ناحية مفهوم فكري أو سياسي. ثم نبحث بحثا موجزا عن نماذج استثمار أموال الوقف وتطور استثمار حديث } \\
& \text { في إدارة المالية الإسلامية و نقارن بينها وبين تخطيط استثمار وكالة إدارة أموال الحج. وبالإضافة أن نبحث عن كيفية حكومة الإدارة } \\
& \text { والاستثمار اللاتي نفذها المملكة العربية السعودية وبخاصة استثمار أموال الوقف الحبيب بوغاك رمه الله. في آخر هذا البحث، يبين } \\
& \text { بعض النقاط عن سبب احتياج استثمار وكالة إدارة أموال الحج في المملكة العربية السعودية مع توصيات استراتيجية ليكون هذا الاستثمار } \\
& \text { اختراقا جديدا في بجال إدارة أموال الحج أو إدارة أموال وقف الأمة. } \\
& \text { مفتاح الكلمات: وكالة إدارة أموال الحج، الاستثمار، الحبيب بوغاك؛ بيت الأشي. }
\end{aligned}
$$

Abstract

The Indonesian Hajj Fund Management Agency (BPKH) initial planning to invest in Saudi Arabia particularly at Waqf Baitul Asyi, Mecca has taken a center stage in the Indonesian media and generating unintended polemics within the community. This paper is trying to put these polemics into perspective by highlighting the profile of BPKH that was mandated by the regulations and tracing the history of Indonesian waqf assets in Saudi Arabia. This will be followed by discovering the reason behind the polemics from a conceptual and political point of view. As a comparison to BPKH's investment planning, several models of waqf properties development and investment as well as a new breakthrough in Islamic finance will be discussed in detail. After that, the discussion on the waqf governance and waqf investment in Saudi Arabia in relation to Waqf Baitul Asyi will be presented here. This write-up will also highlight several points pertaining to why BPKH should carry on their planning to invest in Saudi Arabia as well as giving strategic recommendations to ensure BPKH's investment will be a breakthrough in terms of hajj fund management and development of waqf assets.

Key Words: BPKH, Investment, Waqf, Habib Bugak, Baitul Asyi.

Abstrak

Rencana Badan Pengelola Keuangan Haji (BPKH) untuk melakukan investasi di Arab Saudi, khususnya pada tanah wakaf Baitul Asyi di Mekkah sempat hangat diberitakan oleh berbagai media dan menimbulkan pro dan kontra dalam masyarakat. Artikel ini bertujuan untuk menengahi polemik ini dengan melihat sekilas tentang profil BPKH sesuai dengan amanah regulasi yang berlaku diikuti dengan menapaktilasi sejarah wakaf Indonesia di Arab Saudi. Tulisan ini akan dilanjutkan dengan menganalisa wacana pro dan kontra yang berkembang untuk mengetahui faktor penyebabnya baik dari sisi konsepsi ataupun politis. Kemudian pembahasan singkat mengenai model-model pembiayaan harta wakaf serta beberapa terobosan baru investasi dalam dunia keuangan 
Islam akan disajikan sebagai perbandingan bagi rencana investasi BPKH. Selanjutkan akan dibahas bagaimana mekanisme tata kelola dan investasi yang selama ini dilakukan di Arab Saudi terutama sekali berkaitan dengan investasi terhadap tanah wakaf Habib Bugak. Bagian terakhir tulisan ini akan menguraikan beberapa poin mengenai mengapa perlunya BPKH berinvestasi di Arab Saudi yang akan diikuti dengan rekomendasi strategis supaya investasi yang BPKH lakukan dapat menjadi salah satu terobosan baru baik dalam pengelolaan dana haji ataupun pengembangan aset wakaf milik umat.

Kata Kunci: BPKH, Investasi, Wakaf, Habib Bugak, Baitul Asyi.

\section{A. Latar Belakang}

Pada 26 Juli 2017, Pemerintah Indonesia melakukan satu terobosan baru dengan pelantikan secara resmi anggota Badan Pengelola Keuangan Haji (BPKH) oleh Presiden Joko Widodo. BPKH ini dibentuk berdasarkan amanah Undang-Undang Nomor 34 Tahun 2014 tentang Pengelolaan Keuangan Haji. Berdasarkan pasal 1 Undang-Undang ini, yang dimaksud dengan Keuangan Haji adalah semua hak dan kewajiban pemerintah yang dapat dinilai dengan uang terkait dengan penyelenggaraan ibadah haji serta semua kekayaan dalam bentuk uang atau barang yang dapat dinilai uang sebagai akibat pelaksanaan hak dan kewajiban tersebut, baik yang bersumber dari jamaah haji maupun sumber lain yang sah dan tidak mengikat.

Tata kelola keuangan haji ini sebelumnya berada di bawah Kementerian Agama. Mengingat antusiasme masyarakat Indonesia untuk menunaikan ibadah haji semakin besar, maka dana haji ini pun dari tahun ke tahun juga terus meningkat. Di sisi lain, walaupun Indonesia adalah negara pemeluk Islam terbesar di dunia, namun kuota haji untuk Indonesia juga masih terbatas. Impaknya secara otomatis terjadi penumpukan akumulasi dana haji. Oleh karena itu, dirasa perlu untuk mengelola dana Keuangan Haji ini secara profesional melalui sebuah lembaga yang profesional pula. Kenyataan ini tercermin dari tujuan pengelolaan Keuangan Haji yang dinyatakan dalam undang-undang iaitu meningkatkan kualitas penyelenggaraan ibadah haji, rasionalitas dan efisiensi penggunaan biaya penyelenggaraan ibadah haji dan manfaat bagi kemaslahatan umat Islam. ${ }^{1}$

Pengesahan undang-undang ini dapat dikatakan sebagai kelanjutan daripada semangat reformasi dalam berbagai lembaga yang berkaitan dengan ekonomi umat Islam. $^{2}$ Misalnya saja lahirnya Undang-Undang Pengelolaan Zakat No. 38 tahun 1999 yang kemudian direvisi dengan Undang-Undang Pengelolaan Zakat No. 23 tahun 2011. Kemudian diikuti dengan kelahiran Undang-Undang Nomor 41 tahun 2004 untuk mengatur tata kelola wakaf.

Di satu sisi kelahiran Badan Pengelola Keuangan Haji, yang selanjutnya disingkat BPKH, semakin mempertegas posisi lembaga ekonomi Islam dalam hukum nasional. Namun sejak awal kelahirannya sudah ada pro dan kontra mengenai BPKH. ${ }^{3}$ Ada yang menyambut gembira kelahiran $\mathrm{BPKH}$ mengingat di negeri jiran kita Malaysia, lembaga khusus pengelolaan keuangan haji sudah ada sejak tahun 1969 melalui lembaga yang diberi nama Lembaga Urusan Tabung Haji (LUTH) Malaysia. ${ }^{4}$ Lembaga ini pada tahun 1995 ditukar namanya menjadi Lembaga Tabung Haji

\footnotetext{
${ }^{1}$ Pasal 3 Undang-Undang Republik Indonesia Nomor 34 Tahun 2014 Tentang Pengelolaan Haji. Undang-Undang ini disahkan di Jakarta pada 17 Oktober 2014

${ }^{2}$ Untuk mengetahui secara mendetail dinamika dan sejarah perkembangan lembaga filantropi Islam seperti zakat dan wakaf beserta kontestasi antara masyarakat sipil dan negara, lihat Amelia Fauzia, Filantropi Islam: Sejarah Kontestasi Masyarakat Sipil dan Negara di Indonesia”, Yogyakarta: Gading Publishing, 2016, hal. 1-376

${ }^{3}$ Untuk mengetahui dinamika dan proses kelahiran BPKH dan lembaga pengelola Keuangan Haji sebelumnya, lihat Muhammad Arief Rahman, "Proses Pembentukan Badan Pengelola Keuangan Haji: Sebuah Kajian Kebijakan Publik" (Skripsi, Universitas Islam Negeri Syarif Hidayatullah Jakarta, 2016), hal. 34-83

${ }^{4}$ Mengenai sejarah kelahiran Tabung Haji, baca https://www.tabunghaji.gov.my/index.php/en/corporate/corporate-information/ about-us, diakses pada 29 November 2018. Baca juga, Sharifah binti Ismail, "The Hajj From Malaysia: Its History, Management and Impact on The Malay Society, 1975-2005” (Disertasi Doktoral, International Islamic University Malaysia, December 2016), hal. 75-122
} 
dan disebut sebagai Tabung Haji ataupun dengan akronim TH. Di sisi lain, ada kekhawatiran bahwa pengelolaan keuangan haji akan disalahgunakan untuk kepentingan politis kelompok tertentu. Kelahiran Peraturan Pemerintah Nomor 5 Tahun 2018 Tentang Pelaksanaan Undang-Undang Nomor 34 Tahun 2018 Tentang Pengelolaan Haji, kembali melahirkan polemik mengenai BPKH. Salah satu penyebab utama polemik itu adalah adanya rencana BPKH untuk melakukan investasi langsung di luar negara, salah satu poin yang diatur dalam regulasi itu.

Polemik ini semakin membesar ketika BPKH memaparkan rencananya untuk melakukan investasi pada tanah wakaf Baitul Asyi di Mekkah. Kecaman dan penolakan pun bermunculan dari segala lapisan masyarakat, terutamanya para politisi di provinsi Aceh, yang memanfaatkan keadaan ini untuk tujuan pribadi mereka. Oleh karena itu perlu dilakukan studi kritis untuk menengahi polemik mengenai rencana investasi BPKH. Studi ini juga akan memaparkan bahwa sebenarnya terobosan untuk melakukan investasi pada aset wakaf Baitul Asyi adalah sebuah inisiatif cerdas dan berpandangan jauh ke depan. Langkah ini nantinya akan memberikan impak positif bagi BPKH dalam memahami seluk-beluk tata kelola sektor wakaf yang dapat direplikasi dalam sektor wakaf di tanah air kita.

\section{Kajian Riset Sebelumnya}

Studi-studi mengenai investasi dana haji Indonesia di Arab Saudi baik pada aset wakaf ataupun aset yang lain belum pernah dilakukan. Hal ini mungkin disebabkan belum pernah dilakukannya investasi dana Keuangan Haji di luar negeri selama ini. Apalagi BPKH sendiri masih merupakan lembaga baru yang masih dalam tataran rencana untuk melakukan investasi di Arab Saudi.
Sebelum ini terdapat penelitian yang dilakukan terhadap investasi dana haji sewaktu masih dikelola oleh Kementerian Agama. Skripsi yang berjudul, Optimalisasi Investasi Dana Biaya Penyelenggaraan Ibadah Haji Tahun 2006 oleh Ditjen Penyelenggaraan Haji dan Umrah Kementerian Agama Republik Indonesia, ditulis oleh Alwi Rahman tahun 2017. ${ }^{5}$ Skripsi ini berupaya mengungkapkan bagaimana mekanisme penempatan dana setoran Biaya Penyelenggaraan Ibadah Haji (BPIH) dan bagaimana sistem investasi dan pengelolaan BPIH serta apa manfaat dana optimalisasi setoran BPIH itu. Hasil penelitian ini menyebutkan bahwa optimalisasi dana BPIH yang dikelola oleh Kementerian Agama meningkat sehingga dapat digunakan untuk pelayanan jamaah haji yang lebih baik di masa mendatang. Temuan ini merupakan sebuah indikasi bahwa ketika dana Keuangan Haji sekarang ini dikelola secara terpisah oleh sebuah lembaga profesional, maka sudah tentu peluang untuk mendapatkan imbal hasil yang lebih besar semakin terbuka lebar, apalagi bila penempatan dana investasi itu dilakukan di tempat yang terkait rapat dengan logistik haji itu sendiri di Arab Saudi.

Selanjutnya, dalam kaitan dengan mengapa perlunya BPKH dibentuk, jika dana yang dikelola selama ini juga sudah efektif dan efisien, penelitian yang dilakukan oleh Muhammad Arief Rahman ${ }^{6}$ menunjukkan bahwa tata kelola dana haji ini akan lebih optimal dengan kelahiran BPKH yang fokus tugasnya adalah untuk lebih mengoptimalkan pengelolaan dananya dengan berbagai instrumen investasi syariah yang ada. Hasil penelitian itu menegaskan bahwa pembentukan BPKH adalah sebuah keniscayaan untuk pengembangan dan pengelolaan dana haji melihat berbagai inovasi positif yang dapat ditawarkan dan dilakukan melalui lembaga baru ini.

Untuk studi investasi wakaf di Mekkah, ada beberapa penelitian yang dilakukan di luar negara

\footnotetext{
${ }^{5}$ Untuk mengetahui secara mendalam hasil kajian ini, lihat, Alwi Rahman, "Optimalisasi Investasi Dana Biaya Penyelenggaraan Ibadah Haji Tahun 2006 oleh Ditjen Penyelenggaraan Haji dan Umrah Kementerian Agama Republik Indonesia”, (Skripsi, Universitas Islam Negeri Syarif Hidayatullah Jakarta, 2017), hal. 1-74.

${ }^{6}$ Lihat, Muhammad Arief Rahman, "Proses Pembentukan Badan Pengelola Keuangan Haji", hal. 1-87.
} 
yang menunjukkan bagaimana prospektifnya pengembangan wakaf di sana dengan inovasi instrumen sukuk yang mungkin saja dapat diikuti oleh BPKH setelah dilakukan studi kelayakan terlebih dahulu. Hydzulkifli dan Asmak dalam kajian mereka mencoba menjelaskan dua konsep memajukan harta wakaf baik secara tradisional ataupun dengan pembangunan cara modern. ${ }^{?}$ Mereka secara spesifik juga memaparkan bagaimana penerbitan sukuk alintifa'a mampu membangun aset wakaf di Mekkah. Efektifnya sukuk al-intifa'a ini dalam membangun tanah wakaf yang kemudian didirikan Menara Zam Zam di atasnya juga menjadi salah satu tema yang diangkat oleh Securities Commission Malaysia dalam memperkenalkan berbagai integrasi produkproduk keuangan Islam dengan sektor wakaf. ${ }^{8}$

Kajian-kajian di atas sebelumnya telah diperkaya dengan berbagai literatur yang menerangkan banyaknya aset wakaf Indonesia di luar negeri terutama di Mekkah. Di antaranya adalah studi yang dilakukan oleh orientalis Snouck Horgronje ketika dia meneliti komunitas "Jawi" di Mekkah.9 Selain di Mekkah, ternyata pada zaman dahulu, banyak juga aset-aset wakaf yang dimiliki oleh orang Aceh di negara lain. Izrin Muaz Md Adnan ${ }^{10}$ mencatat bahwa Tunku Syed Husein pada tahun 1808 telah mewakafkan satu masjid di Pulau Pinang yang sekarang ini dikenal dengan nama Masjid Melayu Lebuh Aceh. Tunku
Syed Husein ternyata kemudian juga mewakafkan 13 rumah yang berada di Jalan Chulia masingmasing nomor 103, 105, 107, 113, 115 dan 117 dan nomor 49, 55, 57, 59, 77, 79 dan 81 di Jalan Acheen juga di Pulau Pinang.

Dari studi kepustakaan di atas, dapat disimpulkan bahwa dengan kondisi sekarang ini, peluang BPKH mengoptimalkan imbal balik dana haji dengan berinvestasi di Arab Saudi khususnya pada aset yang berupa tanah wakaf adalah terbuka lebar. Tentunya BPKH harus menyambut baik peluang terbuka ini dalam rangka mengelola dana Keuangan Haji secara efektif dan efisien serta sesuai dengan amanah yang diberikan melalui regulasi Undang-Undang No. 34 tahun 2014 tentang Pengelolaan Keuangan Haji.

\section{Profil BPKH}

BPKH adalah lembaga yang melakukan pengelolaan Keuangan Haji. ${ }^{11}$ BPKH bertugas mengelola Keuangan Haji yang meliputi penerimaan, pengembangan, pengeluaran, dan pertanggungjawaban Keuangan Haji. ${ }^{12}$ BPKH ini berkedudukan dan berkantor pusat di ibukota negara Republik Indonesia dan dapat memiliki kantor perwakilan di provinsi dan kantor cabang di kabupaten/kota. ${ }^{13}$ Selanjutnya disebutkan bahwa dalam menjalankan tugasnya BPKH berwenang untuk menempatkan dan menginvestasikan Keuangan Haji sesuai dengan prinsip syariah, kehati-hatian, keamanan, dan nilai manfaat serta

\footnotetext{
${ }^{7}$ Lihat, Hydzulkifli Hashim Omar dan Asmak Ab Rahman, "Pembiayaan Pembangunan Harta Wakaf Menggunakan Sukuk", Kuala Lumpur, Penerbit Universiti Malaya, 2015, hal. 1-158.

${ }^{8}$ Lihat, Securities Commission Malaysia, "Waqf Assets: Development, Governance and The Role of Islamic Capital Market", Kuala Lumpur, Securities Commission Malaysia, 2014, hal. 38-40.

${ }^{9}$ Untuk mengetahui lebih mendalam tentang komunitas 'Jawi' di Mekkah, lihat, Snouck Hurgronje, C. "Mecca in the Latter Part of the 19th Century, Daily Life, Customs and Learning of The Moslims of the East-Indian Archipelago", diterjemahkan oleh J.H. Monahan, Leiden: Brill, 1931, hal. 229-312. Hasil studi ini dirujuk oleh berbagai literatur yang mengkaji sejarah perkembangan wakaf di Indonesia terutama sekali berkaitan dengan aset wakaf yang pernah dimiliki di luar negara. Misalnya, lihat, Tuti A. Najib dan Ridwan al-Makassary (ed.), "Wakaf, Tuhan dan Agenda Kemanusiaan", Jakarta, Centre for Study of Religion and Culture (CSRC) Universitas Islam Negeri (UIN) Syarif Hidayatullah, 2006, hal. 75-76.

${ }^{10}$ Lihat, Izrin Muaz Md Adnan, "A History of the Acheen Street Malay Enclave from Oral History Accounts”, Journal of the Malaysian Branch of the Royal Asiatic Society, vol. 85, Part 1, No. 302 June 2012, p. 6.

${ }^{11}$ Pasal 1 Undang-Undang Republik Indonesia Nomor 34 Tahun 2014 Tentang Pengelolaan Haji, Pasal 1 Peraturan Pemerintah Repblik Indonesia Nomor 5 Tahun 2018 Tentang Pelaksanaan Undang-Undang Nomor 34 Tahun 2014 Tentang Pengelolaan Keuangan Haji.

12 Pasal 22 Undang-Undang Republik Indonesia Nomor 34 Tahun 2014 Tentang Pengelolaan Haji. Kemudian dalam Pasal 1 Peraturan Pemerintah Republik Indonesia Nomor 5 Tahun 2018 Tentang Pelaksanaan Undang-Undang Nomor 34 Tahun 2014 Tentang Pengelolaan Keuangan Haji juga disebutkan bahwa Pengelolaan Keuangan Haji itu meliputi perencanaan, pertanggungjawaban, pelaporan dan pengawasan atas Keuangan Haji.

${ }^{13}$ Pasal 21 Undang-Undang Republik Indonesia Nomor 34 Tahun 2014 Tentang Pengelolaan Haji. Hal senada juga ditegaskan lagi dalam pasal 4 Peraturan Presiden Republik Indonesia Nomor 110 Tahun 2017 Tentang Badan Pengelola Keuangan Haji.
} 
melakukan kerjasama dengan lembaga lain dalam rangka pengelolaan Keuangan Haji. ${ }^{14}$

Mengingat sentralnya peran yang akan dijalankan, BPKH pun sudah menentukan visi, misi dan strategi yang akan mereka tempuh dalam mengemban amanah yang besar ini. Visi BPKH adalah "Menjadi Lembaga Keuangan Haji terpercaya yang memberikan nilai manfaat optimal bagi jamaah haji dan kemaslahatan umat". ${ }^{15}$ Melalui visi ini terlihat bahwa ada dua sasaran yang ingin diraih BPKH dalam memberikan nilai manfaat yang optimal dari keberadaan mereka iaitu jamaah haji khususnya dan kemaslahatan umat pada umumnya. Sisi kemaslahatan umat inilah yang sangat relevan bagi BPKH untuk kemudiannya ikut serta membangun berbagai aset wakaf Indonesia baik di dalam atau di luar negeri. Apalagi sekarang ini di berbagai negara Islam, revitalisasi sektor wakaf sedang mendapatkan momentum.

Selanjutnya BPKH menegaskan bahwa misi utama mereka adalah:

1. Membangun kepercayaan melalui pengelolaan sistem keuangan yang transparan dan modern;

2. Meningkatkan efisiensi dan rasionalitas BPIH melalui kerjasama strategis;

3. Melakukan investasi pada imbal hasil yang optimal dengan prinsip syariah dan mempertimbangkan aspek keamanan, kehatihatian dan profesionalitas;

4. Menciptakan tata kelola dan sistem kerja yang komprehensif dan akuntabel dengan mengembangkan SDM yang berintegritas dan profesional;

5. Memberikan kemaslahatan untuk meningkatkan kesejahteraan umat. ${ }^{16}$

Secara organisasi pula, BPKH ini terdiri badan pelaksana dan badan pengawas. Badan pelaksana adalah unsur pelaksana tugas $\mathrm{BPKH}$ yang berkaitan dengan perencanaan, pelaksanaan, pertanggungjawaban dan pelaporan Keuangan Haji. Badan pelaksana BPKH sekarang ini terdiri dari tujuh bidang iaitu Hukum dan Kepatuhan, Perencanaan dan Pengembangan, Keuangan, Investasi, SDM/ \& Kemaslahatan, Operasional dan Manajemen Risiko. Dewan pengawas pula adalah organ BPKH yang mengawasi perencanaan, pelaksanaan serta pertanggungjawaban dan pelaporan Keuangan Haji. Dewan ini terdiri dari Komite Audit, Investasi \& Risiko, dan Syariah.

Sebagai badan hukum publik yang bertanggung jawab kepada Presiden dan juga sebagai badan yang secara organisasi merupakan kombinasi antara korporasi dan nirlaba, maka keberadaan badan pelaksana dan dewan pengawas merupakan faktor yang sangat penting bagi BPKH dalam menjalankan tugas-tugasnya. Oleh karena itu, ketika badan pelaksana ingin melakukan investasi, katakanlah di luar negeri pada tanah wakaf Baitul Asyi, maka dewan pengawas akan memberikan penilaian untuk seterusnya memberikan persetujuan ataupun tidak setuju dengan rencana investasi Keuangan Haji yang diajukan oleh badan pelaksana. Sebagai langkah antisipasi terhadap kurang hati-hatinya BPKH dalam melakukan investasi, maka Undang-Undang Nomor 34 Tahun 2014 ini, dalam pasal 53, secara tegas menyatakan bahwa anggota pelaksana dan anggota dewan pengawas bertanggung jawab secara tanggung renteng terhadap kerugian penempatan dan/atau investasi Keuangan Haji secara keseluruhan yang ditimbulkan atas kesalahan dan/atau kelalaian dalam pengelolaannya.

Untuk memastikan tata kelola Keuangan Haji berjalan dengan baik, BPKH secara keseluruhan diatur melalui seperangkat aturan hukum yang sangat lengkap mulai dari Undang-Undang, Peraturan Pemerintah, Peraturan Presiden dan

\footnotetext{
${ }^{14}$ Pasal 24 Undang-Undang Republik Indonesia Nomor 34 Tahun 2014 Tentang Pengelolaan Haji.

15 “Pengelolaan Dana Haji dan Rencana Strategis BPKH 2018-2022”,http://bpkh.go.id/hal-visi-dan-misi-bpkh.html, diakses pada 29 November 2018.

${ }^{16}$ Ibid. Dalam dokumen yang sama juga disebutkan bahwa untuk mewujudkan visi dan misinya, BPKH akan menjalankan berbagai strategi yang meliputi target finansial, pelayanan/kerjasama, proses internal dan sumber pengembangan.
} 
bermacam-macam peraturan yang dibuat oleh BPKH sendiri yang dikenal dengan Peraturan Badan Pengelola Keuangan Haji. Dengan demikian secara regulasi tidak salah kalau kita katakan, BPKH sudah cukup kuat sehingga dalam implementasinya, terutama dalam hal investasi Keuangan Haji, diharapkan benar-benar memberi nilai manfaat yang optimal bagi jamaah haji dan kemaslahatan umat.

\section{Sejarah Wakaf Indonesia di Arab Saudi}

Christian Snouck Hurgronje menyebutkan bahwa banyak sekali rumah-rumah wakaf di Mekkah yang dimiliki dan dinamakan sesuai dengan daerah asal mereka oleh masyarakat yang yang dikenal dengan orang Jawi, sebutan untuk orang yang berasal dari kawasan Nusantara ketika itu. Di antara rumah wakaf yang sangat terkenal ketika itu adalah rumah wakaf Aceh, rumah wakaf Banten dan rumah wakaf Pontianak. ${ }^{17}$ Salah satu di antara rumah wakaf itulah yang kini dikenali dengan Baitul Asyi. Dalam buku itu, ia juga menyebutkan bahwa ada beberapa orang Aceh yang bersiap-siap untuk pulang ke Aceh dengan tujuan mengumpulkan uang untuk kembali membeli rumah-rumah di kota Mekkah untuk dijadikan rumah wakaf. ${ }^{18}$ Ini adalah suatu indikasi bahwa pada masa itu budaya dan tradisi wakaf di Aceh khususnya dan di daerah lain umumnya sudah sangat kuat.

Baitul Asyi ini pada mulanya adalah wakaf sepetak tanah dengan sebuah rumah dua tingkat di atasnya yang berada di daerah Qusyasyiah. Wakaf ini dilakukan oleh Habib Bugak Asyi pada tahun 1809 ketika beliau datang ke hadapan hakim Mahkamah Syariah Mekkah dan mengutarakan keinginannya untuk mewakafkan tanah dan rumah seperti tersebut di atas yang kemudian dituangkan ke dalam Penetapan Mahkamah Mekkah tentang Ikrar Wakaf Habib Bugak Asyi.
Al Yasa' Abubakar menyebutkan bahwa ketika musim haji tahun 2002 Syeikh Abdul Ghani Mahmud Asyi, selaku nazhir saat itu, menyerahkan salinan Penetapan Mahkamah Mekkah tentang Ikrar Wakaf Habib Bugak Asyi (Akta Ikrar Wakaf) kepada Abdullah Puteh, Gubernur Aceh pada masa itu. Naskah aslinya pula disimpan beliau selaku nazhir di Mahkamah Mekkah. ${ }^{19}$

Dalam Akta Ikrar Wakaf itu disebutkan bahwa Habib Bugak Asyi ketika mewakafkan tanah dan rumah itu menetapkan beberapa syarat untuk dilaksanakan oleh nazhir wakaf kelak. ${ }^{20}$ Syarat yang pertama, rumah tersebut hendaklah dijadikan tempat tinggal jamaah haji asal Aceh yang datang ke Mekkah untuk menunaikan haji dan juga tempat tinggal orang asal Aceh yang menetap di Mekkah. Kedua, kalau sekiranya karena sesuatu sebab tidak ada lagi orang Aceh yang datang ke Mekkah untuk naik haji maka rumah wakaf ini digunakan untuk tempat tinggal para pelajar "Jawi" (istilah yang digunakan untuk menyebut Wilayah Asia Tenggara ketika itu) yang belajar di Mekkah. Ketiga, seandainya karena sesuatu sebab mahasiswa Asia Tenggara pun tidak ada lagi yang belajar di Mekkah maka rumah wakaf ini digunakan untuk tempat tinggal mahasiswa Mekkah yang belajar di Masjid Haram. Terakhir sekiranya mereka ini pun tidak ada juga maka wakaf ini hendaklah diserahkan kepada Imam Masjid Haram untuk membiayai keperluan Masjid Haram.

Ketika terjadi perluasan Masjid Haram sekitar tahun lima puluhan, tanah dan rumah wakaf Baitul Asyi itu kena gusur. Tanah dan rumah yang digusur itu diberikan kompensasi oleh pemerintah Arab Saudi yang diberikan kepada nazhir wakaf Baitul Asyi. Nazhir wakaf kemudian memanfaatkan uang kompensasi ganti rugi itu untuk membeli aset dalam bentuk tanah di lokasi

\footnotetext{
${ }^{17}$ Snouck Hurgronje, C. "Mecca in the Latter Part of the 19th Century, Daily Life, Customs and Learning of The Moslims of the East-Indian Archipelago", hal. 274.

${ }^{18}$ Ibid.

${ }^{19}$ Lihat Al Yasa' Abubakar, Mengenal Wakaf Habib Bugak Asyi (Baitul Asyi Mekah), Buletin Narit Geutanyo, Jilid 3, No. 6, 2009 , Kg. Aceh Yan, Kedah, Malaysia, Ikatan Masyarakat Aceh Malaysia (IMAM), 2009, hal. 5-6.

${ }^{20} \mathrm{Ibid}$.
} 
yang strategis setelah mendapatkan izin dari Mahkamah Mekkah selaku pengawas aset wakaf Baitul Asyi.

Selain dari aset wakaf yang kini dikenal dengan nama Baitul Asyi itu, sebenarnya masih banyak lagi aset harta wakaf Aceh yang lain. Anwar Fuadi Salam menyebutkan bahwa dalam penelusurannya, paling kurang masih ada sekitar 16 lokasi lagi rumah wakaf Aceh pada suatu ketika dahulu, yaitu: Rumah Wakaf Syeh Muhammad Saleh Asyi dan isterinya Syaikah Asiah di Qassyasiah, Rumah WakafSulaiman bin Abdullah Asyi di kawasan Suq Allail, Rumah Wakaf Muhammad Abid Asyi, Rumah Wakaf Abdul Aziz bin Marzuki, Rumah Wakaf di kawasan Suqlail, Rumah Wakaf di kawasan Zugag Aljabal, Rumah Wakaf di kawasan Gazzah, Rumah Wakaf di kawasan Khariq, Rumah Wakaf di jalan Suq Arab Mina, Rumah Wakaf Muhammad Saleh Ashy di Mina, Rumah Wakaf Datuk Muhammad Abid Panyang Aceh di Mina, Rumah Wakaf di kawasan Balad, Jeddah, Rumah Wakaf di kawasan Aziziah Mekkah, Rumah Wakaf di Taif, Rumah Wakaf di kawasan Hayyi Alhijrah Mekkah, dan Rumah Wakaf di kawasan Hayyi Ar-Raudah Mekkah. ${ }^{21}$

Mengingat rekam jejak wakaf Indonesia di Arab Saudi yang gemilang itu dan ada di antara aset wakaf itu yang sudah tidak diketahui lagi keberadaannya, dengan kegiatan investasi yang dilakukan oleh BPKH kelak, mungkin saja sedikit demi sedikit aset-aset yang lama itu termasuk rumah wakaf Banten dan Pontianak akan dapat ditelusuri kembali. Tentunya hal ini akan membuka lembaran baru sejarah panjang wakaf Indonesia di Arab Saudi.
5. Sekilas Pro dan Kontra Rencana Investasi BPKH di Arab Saudi

Pada bulan Maret 2018 yang lalu, berita-berita mengenai rencana BPKH untuk melakukan investasi di tanah wakaf Baitul Asyi di Mekkah hangat diberitakan oleh berbagai media. Pemberitaan ini muncul pasca Wakil Presiden Republik Indonesia Jusuf Kalla menerima Ketua Badan Pelaksana BPKH Anggito Abimanyu yang didampingi oleh Alwi Shihab, Utusan Khusus Presiden untuk Timur Tengah dan Organisasi Kerjasama Islam (OKI), di Istana Wakil Presiden. BPKH dalam pertemuan itu melaporkan rencana investasinya di Arab Saudi. Salah satu rencana investasi yang ingin dilakukan adalah membangun hotel di atas tanah wakaf milik Pemerintah Aceh yang ada di Mekkah. ${ }^{22}$ Kemudian Anggito menambahkan bahwa tanah itu sangat strategis karena berlokasi sekitar 400 meter dari Masjid Haram. Dia juga menjelaskan bahwa BPKH akan bertemu dengan beberapa pihak investor di Arab Saudi termasuk dengan Islamic Development Bank (IDB) untuk menjajaki beberapa kesempatan investasi yang lain di negara itu. Kerjasama antara BPKH dan IDB tentunya untuk menempatkan dana tabungan haji dalam instrumen syariah untuk menghasilkan imbal hasil secara optimal yang nantinya akan dikembalikan kepada biaya operasional haji ataupun jamaah haji tunggu.

Wakil Presiden Jusuf Kalla dalam pertemuan itu juga mengarahkan agar BKPH dapat menginvestasikan dana haji di Arab Saudi untuk menghilangkan risiko valas dan juga imbal hasilnya cukup besar. ${ }^{23}$ Hal senada juga dipertegas oleh Alwi Shihab yang memastikan bahwa dana haji itu akan ditempatkan dalam instrumen syariah dengan skema bagi hasil. Ia berargumen bahwa investasi dana BPKH itu paling tepat adalah di Arab Saudi terutama menyangkut dengan jamaah

\footnotetext{
${ }^{21}$ Lihat, Anwar Fuadi Salam, Menelusuri Bayt al-Asy di Tanah Suci (Bagian 2), http://bwi.or.id/index.php/in/publikasi/artikel/540menelusuri-bayt-al-asy-di-tanah-suci-bagian-2-html, diakses pada 29 November 2018.

22 Lihat, "BPKH akan Investasi di atas Tanah Wakaf Aceh di Arab Saudi", https://www.republika.co.id/berita/http://www. republika.co.id/berita/jurnal-haji/berita-jurnal-haji/18/03/09/p5b9kq396-bpkh-akan-investasi-di-atas-tanah-wakaf-aceh-di-arab-saudi, diakses 29 November 2018. Lihat juga “Temui JK, BPKH Lapor Rencana Pengelolaan Tanah Wakaf di Makah”, https://news.detik.com/ berita/3907326/temui-jk-bpkh-lapor-rencana-pengelolaan-tanah-wakaf-di-makah, diakses pada 29 November $2018 .{ }^{21}$ Lihat, Anwar

${ }^{23}$ Ibid.
} 
haji baik untuk sektor perumahan, penerbangan, ataupun layanan lainnya. ${ }^{24}$

Wacana yang dipaparkan oleh BPKH itu segera saja menjadi viral dan menjadi bahan diskusi oleh berbagai lapisan masyarakat, terutama di Aceh. Pro dan kontra pun terjadi, masing-masing pihak memiliki cara pandang yang berbeda dengan memberikan justifikasi yang berbeda pula. Pihak yang kontra, mulai dari politisi, mahasiswa, akademisi, dan rakyat biasa segera saja mengeluarkan pernyataan untuk menentang rencana $\mathrm{BPKH}$ ini.

Partai Aceh (PA) dalam siaran persnya mengatakan bahwa mereka menolak dengan tegas rencana BPKH untuk mengambil alih pengelolaan tanah wakaf rakyat Aceh (Baitul Asyi). "Kami menolak tegas rencana tersebut dan meminta Presiden Joko Widodo (Jokowi) agar meninjau kembali rencana BPKH RI untuk mengambil alih pengelolaan Tanah Wakaf Rakyat Aceh di Arab Saudi tersebut", ${ }^{25}$ demikian isi siaran pers yang dikirimkan oleh Syardani M. Syarif juru bicara Partai Aceh yang dikirimkan ke berbagai media di daerah maupun media nasional. Syardani kemudian menambahkan bahwa selama ini, Baitul Asyi sudah dikelola dengan baik oleh Nazir Wakaf Habib Bugak dan tidak ada permasalahan apapun sehingga ia meminta kepada Pemerintah RI untuk tidak mengganggu aset milik rakyat Aceh di manapun berada. Ia juga menandaskan bahwa mereka akan berjuang sekuat tenaga untuk mempertahankan hak rakyat Aceh.

Hal senada juga disampaikan oleh anggota DPR-RI asal Aceh dari fraksi PKS, M. Nasir Djamil yang meminta Pemerintah Aceh untuk menolak rencana BPKH yang ingin berinvestasi di tanah wakaf milik rakyat Aceh di Mekkah.
Ia juga meminta BPKH lebih sensitif terhadap perasaan masyarakat Aceh yang selama ini sering dikecewakan oleh Pemerintah Pusat terkait wakaf atau sumbangan lain yang diserahkan. Selanjutnya Nasir Djamil meminta kepada BPKH agar khusus untuk pengelolaan dan skema investasi terhadap tanah wakaf milik Aceh tetap dikelola oleh Pemerintah Aceh agar sesuai dengan ikrar wakaf dan peruntukannya. ${ }^{26}$ Langkah dramatis diambil oleh salah seorang anggota DPD dari Aceh, H. Sudirman yang menulis surat kepada Nazir Wakaf Baitul Asyi di Mekkah untuk menyatakan penolakan terhadap rencana BPKH. ${ }^{27}$

Pada hari Rabu, 14 Maret 2018 pula para mahasiswa yang tergabung dalam Forum Rakyat Aceh Menggugat mengadakan unjuk rasa di kantor Gubernur Aceh untuk meminta penjelasan langsung dari Gubernur Aceh tentang rencana BPKH melakukan investasi di tanah wakaf Baitul Asyi. Mahasiswa itu dalam orasinya menolak semua rencana BPKH dan mengaku siap untuk mempertahankan tanah wakaf itu seraya mencontohkan bahwa selama ini banyak hasil alam Aceh seperti minyak, gas, emas dan hasil bumi lainnya telah diambil dan dimanfaatkan oleh Pemerintah Pusat. Kemudian mereka menanyakan apa yang akan diperoleh oleh Aceh setelah BPKH berinvestasi yang kemudian diakhiri dengan pernyataan supaya pemerintah tidak lagi memberikan harapan palsu kepada warga Aceh. ${ }^{28}$

Maraknya penolakan ini membuat Pemerintah Aceh akhirnya mengeluarkan pernyataan resmi mereka melalui Kepala Biro Humas dan Protokol Pemerintah Aceh ketika itu, Mulyadi Nurdin. Pemerintah Aceh menyatakan bahwa mereka akan bersama rakyat Aceh dalam mengawal Baitul Asyi di Arab Saudi. Jadi Pemerintah Aceh akan

\footnotetext{
${ }^{24}$ Ibid.

25 Lihat, "Soal Tanah Wakaf, Partai Aceh Tolak Rencana BPKH", https://www.republika.co.id/berita/jurnal-haji/berita-jurnalhaji/18/03/11/p5f1jw396-soal-tanah-wakaf-partai-aceh-tolak-rencana-bpkh, diakses pada 29 November 2018.

${ }^{26}$ Lihat, "Anggota DPR Tolak Niat BPKH Kelola Tanah Wakaf Rakyat Aceh", https://www.republika.co.id/berita/jurnal-haji/beritajurnal-haji/18/03/10/p5dfmy396-anggota-dpr-tolak-niat-bpkh-kelola-tanah-wakaf-rakyat-aceh, diakses pada 29 November 2018.

${ }^{27}$ Lihat, "Haji Uma Surati Nazir Wakaf Aceh di Arab Saudi, Tolak Rencana Investasi Indonesia di Baitul Asyi", http://aceh. tribunnews.com/2018/03/13/haji-uma-surati-nazir-wakaf-aceh-di-arab-saudi-tolak-rencana-investasi-indonesia-di-baitul-asyi, diakses pada 29 November 2018.

${ }^{28}$ Lihat, "Mahasiswa Gelar Aksi Tolak Rencana Investasi BPKH di Baitul Asyi", http://portalsatu.com/read/news/mahasiswa-gelaraksi-tolak-rencana-investasi-bpkh-di-baitul-asyi-41472, diakses pada 29 November 2018.
} 
menolak upaya yang dilakukan untuk mengalihkan pengelolaan tanah wakaf Baitul Asyi kepada pihak lain selain nazir wakaf. Mulyadi Nurdin menambahkan bahwa sebenarnya tanah wakaf itu bukan aset Pemerintah Aceh ataupun Pemerintah Indonesia, akan tetapi berada langsung di bawah manajemen Nazir Wakaf Baitul Asyi di Arab Saudi sehingga dalam hal ini Pemerintah Aceh atau Pemerintah Indonesia tidak bisa melakukan apa-apa intervensi terhadap aset wakaf di Mekkah itu. ${ }^{29}$

Di sisi lain ada juga upaya untuk mencegah polemik ini berkepanjangan. Abdullah Puteh, mantan Gubernur Aceh yang pernah berjumpa langsung dengan Nazir Wakaf Baitul Asyi pada tahun 2002, mencoba memperjelas status wakaf Baitul Asyi sesuai dengan informasi yang dia dapatkan itu. Dia mengatakan berdasarkan ikrar wakaf yang diikrarkan oleh Habib Bugak itu, tidak ada celah bagi BPKH atau pemerintah pusat untuk mengambil alih hak pengelolaannya. Akan tetapi kalau untuk ikut serta menyertakan modal dalam pengelolaan Baitul Asyi, maka peluang itu ada, namun tidak bisa langsung. Haruslah menggunakan jasa dan atas persetujuan nazir yang ada sekarang. Ini pun harus dilakukan sesuai dengan ketentuan hukum Arab Saudi. ${ }^{30}$

Ketika polemik sedang menghangat, Al Yasa' Abubakar dalam satu tulisannya mengatakan beliau merasa terpanggil untuk mendudukkan persoalan ini secara proporsional. ${ }^{31}$ Ia pun kemudian menguraikan sedikit sejarah aset wakaf ini yang bermula dengan diwakafkan oleh seorang yang bernama Habib Abdurrahman atau yang lebih dikenali sebagai Habib Bugak Asyi pada tahun 1809 di Mekkah. Dalam akta wakaf itu jelas disebutkan bagaimana peruntukan dari aset wakaf itu. Bahkan si pewakaf (wakif), telah menunjuk nazir secara turun temurun. Jadi di sini jelas bahwa keliru sekali anggapan bahwa harta itu adalah aset Pemerintah Aceh ataupun harta rakyat Aceh. Kedudukan masyarakat Aceh atas harta itu hanyalah sebagai penerima manfaat saja. Yang berhak menerima manfaat pun bukan semua rakyat Aceh, akan tetapi hanya yang menunaikan ibadah haji ataupun orang Aceh yang bermukim di sana. Intinya kedudukan masyarakat Aceh adalah pasif, sama sekali tidak terlibat dalam kebijakan pengembangan dan pengelolaan aset itu.

Tata kelola aset wakaf itu sepenuhnya berada di tangan nazir yang diawasi oleh Mahkamah Syariah di sana. Nazir dapat mengambil inisiatif untuk mencari investor mengembangkan tanah wakaf itu. Al Yasa' kemudian menyebutkan sebenarnya nazir pernah meminta Gubernur Aceh ketika itu, Abdullah Puteh, untuk mengajak investor asal Aceh dan Indonesia untuk membangun gedung atau hotel di atas tanah tersebut ${ }^{32}$ Kepada investor itu nantinya akan diberikan hak pengelolaan selama beberapa tahun, seperti lazimnya diberikan kepada pengusaha Arab sendiri. Sayang sekali, ketika itu, tidak ada satu pun investor dari Indonesia yang mahu melakukan investasi di sana. Beliau kemudian mengakhiri tulisannya dengan mengajak semua masyarakat Aceh agar tidak perlu reaktif atas rencana BPKH itu. Kalau betul semua pihak memang peduli dengan harta wakaf, di Aceh masih cukup banyak tanah wakaf yang perlu diurus dengan baik. ${ }^{33}$

Penulis sendiri dalam mensikapi polemik itu kemudian mencoba menerangkan duduk persoalan yang sesungguhnya dengan melihat bagaimana ketentuan mengenai mekanisme tata kelola wakaf di Arab Saudi dan juga

29 Lihat, "Ini Penegasan Pemerintah Aceh Terkait Rencana Investasi BPKH di Tanah Wakaf Baitul Asyi", http://aceh.tribunnews. com/2018/03/14/ini-penegasan-pemerintah-aceh-terkait-rencana-investasi-bpkh-di-tanah-wakaf-baitul-asy, diakses pada 29 November 2018.

${ }^{30}$ Lihat, "Abdullah Puteh Perjelas Status Wakaf Baitul Asyi", http://aceh.tribunnews.com/2018/03/14/abdullah-puteh-perjelas-status-wakafbaitul-asyi?page=all, diakses pada 29 November 2018.

${ }^{31}$ Lihat, Al Yasa' Abubakar, "Baitul Asyi Wakaf Habib Bugak di Mekkah", http://aceh.tribunnews.com/2018/03/19/baitul-asyi-wakafhabib-bugak-di-mekkah?page=all, diakses 30 November 2018.

32 Ibid.

33 Ibid. 
memaparkan cara investasi yang biasa ditempuh dalam pengelolaan aset wakaf di negara itu. ${ }^{34}$ Memahami duduk perkara sangat penting agar tidak terjebak dalam polemik yang sama sekali tidak perlu. Apalagi persoalan ini kemudian dijadikan isu oleh politisi yang sebenarnya sama sekali tidak mengerti kedudukan wakaf Baitul Asyi seperti yang ditunjukkan oleh Nasir Djamil yang meminta Pemerintah Aceh tetap mengelola aset wakaf Baitul Asyi. Ini menunjukkan bahwa dia keliru dalam memahami tata kelola wakaf Baitul Asyi seperti yang telah dipaparkan oleh Al Yasa' Abubakar di mana masyarakat atau pemerintah Aceh tidak ada hak sama sekali untuk mengelolanya dan selama inipun bukan dikelola oleh pemerintah Aceh.

Polemik itu sebenarnya bisa dihindari kalau saja semua pihak memahami dengan baik bagaimana tata kelola aset wakaf di Arab Saudi. Polemik ini juga tidak akan terjadi kalau BPKH sendiri dapat melakukan komunikasi dan menjelaskan dengan baik tentang rencana investasi dan juga bagaimana pola investasi di Arab Saudi. Untung saja kemudian BPKH dengan cepat menjelaskan bahwa yang sedang mereka lakukan adalah penjajakan kerjasama investasi hotel untuk tanah wakaf Aceh yang ada di Mekkah dan tidak ada rencana untuk pengalihan kepemilikan tanah itu. $^{35}$

Bagaimana pula dengan adanya kekhawatiran bahwa investasi ini tidak akan memberikan keuntungan atau malah membawa kerugian kepada BPKH? Lalu bagaimana pula jika BPKH tidak jujur dalam melakukan pengeloaan Keuangan Haji? Hal ini tidak perlu dikhawatirkan secara berlebihan karena sesuai dengan amanah pasal 53, Undang-Undang Nomor 34 Tahun 2014 yang secara tegas menyatakan bahwa anggota pelaksana dan anggota dewan pengawas bertanggung jawab secara tanggung renteng terhadap kerugian penempatan dan/ atau investasi Keuangan Haji secara keseluruhan yang ditimbulkan atas kesalahan dan/atau kelalaian dalam pengelolaannya. Sudah tentu semua anggota BPKH tidak mahu mengambil risiko besar ini. Perkembangan di negeri jiran Malaysia beberapa hari ini juga memberikan satu lagi teladan bahwa BPKH haruslah melakukan tugasnya dengan penuh amanah. Kalau tidak mereka nanti akan berurusan dengan pihak berwajib. Inilah yang sekarang menimpa para petinggi Tabung Haji yang sudah dilaporkan ke pihak berwajib karena kecurangan yang mereka lalukan baik dalam mengelola uang Tabung Haji ataupun tindakan mereka memalsukan laporan keuangan untuk tahun 2016. ${ }^{36}$ Laporan polisi ini dibuat oleh manajemen baru, setelah mereka berhasil mendeteksi kecurangan yang dilakukan oleh para petinggi yang duduk dalam manajemen periode sebelumnya.

6. Model Pembiayaan Harta Wakaf di Arab Saudi

Arab Saudi sebagai negara yang setiap tahunnya banyak menerima tamu baik jamaah haji di musim haji atapun jamaah umrah sepanjang tahun sangat gencar dalam membangun aset wakaf, terutama aset yang berada di kota Mekkah. Salah satu aset wakaf yang berhasil dibangun dan menjadi buah bibir sekarang ini adalah Menara Zam Zam yang memiliki tinggi 33 tingkat. Pengembangan aset ini dilakukan melalui instrumen sukuk alintifa'a yang secara sederhananya berbasis kepada kontrak ijarah.

Sukuk al-intifa'a ini secara sederhana pula dapat kita artikan sebagai sukuk manfaat di mana investor atau pemegang sukuk memiliki hak atas penggunaan manfaat atas aset yang diterbitkan

\footnotetext{
${ }^{34}$ Fahmi M. Nasir, "Investasi Wakaf", http://aceh.tribunnews.com/2018/03/22/investasi-wakaf?page=all, diakses pada 30 November 2018. Artikel inilah yang kemudian penulis kembangkan lebih lanjut untuk disertakan dalam LKTI BPKH ini.

${ }^{35}$ Lihat, "BPKH Jajaki Kerja Sama Investasi Hotel di Tanah Suci", https://www.republika.co.id/berita/jurnal-haji/berita-jurnal-haji/18/03/10/ p5debj396-bpkh-jajaki-kerja-sama-investasi-hotel-di-tanah-suci, diakses pada 30 November 2018. Hal senada juga dapat dilihat pada, "Alasan BPKH Incar Investasi Tanah Wakaf di Arab Saudi", https://www.cnnindonesia.com/ekonomi/20180315165636-78-283318/alasan-bpkh-incar-investasitanah-wakaf-aceh-di-arab-saudi, diakses pada 30 November 2018.

${ }^{36}$ Lihat, "Tabung Haji lodges police reports against former chairman, CEOs, and senior management", http://www.theedgemarkets.com/article/ tabung-haji-lodges-police-reports-against-former-chairman-ceos-and-senior-management, diakses pada 30 November 2018.
} 
penerbit sukuk. Investor hanya memiliki hak manfaat saja tanpa memiliki hak ke atas aset tersebut. Sisi yang menarik dari konsepsi sukuk alintifa'a ini adalah diakuinya manfaat sebagai kelas aset yang baru. Atau lebih spesifiknya hak untuk menggunakan dan mengambil manfaat dalam bentuk izin menggunakan properti yang dibangun dengan skema ini. ${ }^{37}$

Untuk pengembangan Menara Zam Zam ini, otoritas wakaf di Arab Saudi memberikan sebidang tanah wakaf milik Raja Abdul Aziz kepada perusahaan Bin Laden Group melalui kontrak ijarah, selama 28 tahun, untuk dikembangkan dengan konsep Bangun-Bina-Serah (BOT). Bin Laden Group kemudian bekerja sama dengan perusahaan konstruksi dan real estate, Munshaat Real Esatate Projects Co. (Munshaat). Semua biaya konstruksi senilai USD 390 juta akan ditanggung oleh Munshaat. Munshaat kemudian mengeluarkan sukuk yang diberi nama sukuk alintifa'a yang berjumlah USD 390 juta kepada para investor untuk memperoleh modal membangun menara tersebut.

Sukuk al-intifa'a tersebut dijual kepada investor dengan masa matang 24 tahun. Investor mempunyai hak manfaat untuk menggunakan bangunan tersebut, menyewakannya kepada penyewa lain atau bahkan menjualnya kepada investor lain. Harga sewa bangunan itu biasanya tergantung kepada musim, kalau musim haji ia akan lebih mahal, begitu juga kalau musim umrah di bulan puasa. Setelah Menara Zam Zam ini berumur 28 tahun, maka Munshaat akan menyerahkan kembali menara ini kepada lembaga wakaf Arab Saudi melalui Bin Laden Group.

Hydzulkifli dan Asmak ${ }^{38}$ mencoba menerangkan struktur pembiayaan pembangunan Menara Zam Zam dengan instrumen sukuk al-intifa'a melalui skema berikut ini:

1. Lembaga wakaf Arab Saudi mengidentifikasi satu persil tanah, milik Raja Abdul Aziz, yang berpotensi untuk dikembangkan. Lembaga wakaf ini kemudian menyewakan tanah ini kepada Bin Laden Group selama 28 tahun dengan kontrak ijarah. Bin Laden Group ini akan mengembangkan aset wakaf tersebut dengan menggunakan konsep Bangun-GunaSerah (BOT).

2. Bin Laden Group akan membayar harga sewa aset tanah tersebut kepada lembaga wakaf Arab Saudi.

3. Bin Laden Group kemudian bekerjasama dengan Munshaat untuk membangunkan aset itu. Munshaat kemudian mengeluarkan sukuk al-intifa'a sebesar USD 390 juta dengan tujuan mendapatkan dana konstruksi pembangunan itu.

4. Munshaat kemudian menawarkan sukuk intifa'a tersebut kepada calon investor yang mau menanam modal sebagai bukti pemililikan hak manfaat terhadap Menara Zam Zam itu.

5. Dana sebanyak USD 390 berhasil dikumpulkan hanya dalam masa dua minggu saja setelah sukuk al-intifa'a diterbitkan.

6. Dana yang dikumpulkan itu diserahkan kepada Bin Laden Group untuk dijadikan modal membangun Menara Zam Zam.

7. Konstruksi Menara Zam Zam itu dilakukan selama tiga tahun mulai 2003 dan selesai pada tahun 2006.

Keberhasilan model pembiayaan ini merupakan salah satu terobosan baru yang dilakukan oleh Arab Saudi dalam membangun aset wakafnya. Sebelumnya pembiayaan hanya menggunakan sistem Bangun-Serah-Guna (BOT) seperti biasa di mana developer sendiri yang akan mengucurkan dana. Pola ini juga yang dilakukan oleh Nazir Wakaf Baitul Asyi ketika mengembangkan aset tanah wakaf yang dikenal dengan nama wakaf Habib Bugak itu.

${ }^{37}$ Lihat, Securities Commission Malaysia, "Waqf Assets: Development, Governance and The Role of Islamic Capital Market", hal. 38. Lihat juga M. Imam Syairozi dan Septyan Budy Cahya, "Sukuk Al Intifa'a: Integrasi Sukuk dan Wakaf dalam Meningkatkan Produktifitas Sektor Wakaf Pendorong Investasi Pada Pasar Modal Syariah, Jurnal Penelitian Ilmu Manajemen”, Vol II, No. 2, Juni 2016, hal. 386-397.

${ }^{38}$ Hydzulkifli Hashim Omar dan Asmak Ab Rahman, "Pembiayaan Pembangunan Harta Wakaf Menggunakan Sukuk", hal. 101-103. 
Model pembiayaan sukuk al-intifa'a ini membuka peluang sebesar-besarnya bagi investor luar untuk menanamkan modalnya dalam pembangunan aset wakaf di Arab Saudi. Tentunya BPKH yang mengelola dana yang besar dapat mempertimbangkan untuk melakukan investasi melalui instrumen sukuk al-intifa'a terutama karena fleksibilitas yang dimiliki. BPKH dapat segera mengidentifikasi melalui nazir wakaf di Arab Saudi untuk mengetahui investor mana saja yang sudah mahu menjual sukuk alintifa'a mereka, kalau saja BPKH tertarik untuk berinvestasi di Menara Zam Zam yang lokasinya sangat strategis ini.

7. Pemikiran di Luar Kotak Investasi dalam Dunia Keuangan Islam

Selama 40 tahun terakhir, keuangan Islam mengalami kemajuan yang sangat pesat dengan berbagai inovasi pembiayaan. Inovasi pembiayaan yang dilakukan itu merupakan terobosan baru yang kemudian menjadi pemicu pesatnya kemajuan sektor keuangan Islam. Yang lebih menarik lagi, beberapa terobosan baru itu digunakan untuk membangunkan aset wakaf. Di antara inovasi pembiayaan yang patut dijadikan contoh oleh BPKH adalah pertama, pengembangan aset wakaf di Singapura yang menggunakan sukuk musharakah, kedua, pembangunan Menara Zam Zam, di Mekkah, menggunakan sukuk al-intifa'a, ketiga, pembangunan Menara Bank Islam di Malaysia dengan kombinasi pembiayaan istisna dan BOT, serta sukuk yang dikeluarkan oleh perusahan penerbangan Emirates Airline untuk mendanai pembelian pesawat baru mereka. ${ }^{39}$

Di Singapura, sukuk musharakah diperkenalkan untuk mengembangkan bangunan komersial di atas dua petak tanah yang berada di Jalan Bencoolen. Inisiatif ini dilakukan oleh Warees Pte Ltd (Warees), anak perusahaan yang dimiliki oleh Majlis Ugama Singapura (MUIS).
Satu petak tanah yang sebelumnya berdiri masjid tua, berhasil dibangun menjadi kompleks komersial modern yang terdiri dari masjid baru, tiga tingkat gedung komersial super modern dan 12 tingkat apartemen mewah dengan total 84 unit. $^{40}$ Pembiayaan ini dilakukan dengan mengeluarkan sukuk musharakah senilai S\$35 juta yang dibeli oleh investor dalam masa yang singkat. Keberhasilan Warees ini sangat signifikan untuk meningkatkan nilai aset wakaf di Jalan Bencoolen itu dalam masa yang singkat.

Di Mekkah pula seperti sudah dibahas di atas, keberhasilan yang fenomenal dicapai dengan penerbitan sukuk al-intifa'a untuk mengembangkan Menara Zam Zam, yang betul-betul berada di dekat Masjid Haram.. ${ }^{41}$ Kolaborasi antara Ben Laden Group dan Munshaat berhasil memperkenalkan satu inovasi baru dalam produk keuangan Islam melalui hak manfaat yang dijual kepada investor untuk tenor jangka panjang sebanyak 24 tahun. Lebih hebat lagi, produk ini habis terjual kepada investor hanya dalam masa tiga minggu. Sebuah prestasi yang luar biasa mengingat dana yang terkumpul dalam masa singkat itu mencapai USD 390 juta, sesuai dengan jumlah yang diperlukan. Tidak heran, dalam masa tiga tahun pembangunan Menara Zam Zam sudah selesai. Tentunya nilai Menara Zam Zam itupun menjadi semakin tinggi dari waktu ke waktu mengingat letaknya yang sangat strategis itu.

Di Malaysia pula, pembangunan Menara Bank Islam bisa dikatakan sebagai salah satu proyek pengembangan wakaf yang utama di negara itu. ${ }^{42}$ Proyek ini terealisasi dengan kerja sama antara tiga pihak yaitu Majlis Agama Islam Wilayah Persekutuan Kuala Lumpur (MAIWP), Lembaga Urusan Tabung Haji (LUTH) Malaysia dan Bank Islam Malaysia Berhad (BIMB). Bangunan menara itu dibangun di atas tanah wakaf seluas 0.49 hektar peninggalan Ahmad

\footnotetext{
${ }^{39}$ Fahmi M. Nasir dan Hidayatul Ihsan, "Pushing boundaries of waqf financing in Indonesia", http://www.thejakartapost.com/ academia/2018/02/14/pushing-boundaries-of-waqf-financing-in-indonesia.html, diakses pada 30 November 2018.

${ }^{40} \mathrm{Ibid}$.

${ }^{41}$ Ibid
} 
Dawjee Dadabhoy. Mekanisme pembangunannya dilakukan dengan kombinasi BOT dengan konsep wakala, ijarah dan istisna. Menara Bank Islam kemudian menjadi proyek pembangunan tanah wakaf berskala besar pertama di Malaysia. Tabung Haji mengucurkan dana sebesar RM151 juta untuk proyek ini dan berhak atas hak sewa selama 25 tahun. MAIWP sebagai pemegang amanah tanah tersebut akan menerima uang sewa sebanyak RM56.6 juta selama masa tersebut yang akan dibayar secara bertahap oleh Tabung Haji. Tabung Haji sebagai pihak yang telah diberi hak konsesi bangunan ini untuk 25 tahun, berhak untuk menerima semua hasil sewanya. BIMB pula akan menjadi penyewa utama bangunan ini dengan menggunakan sebanyak 30 tingkat dari keseluruhan 34 tingkat. Pada waktu MAIWP menerima bangunan ini kelak, diperkirakan harga bangunan sudah mencapai RM700 juta. Lagi-lagi inovasi pembiayaan berhasil meningkatkan nilai aset wakaf dalam masa yang singkat.

Selanjutnya pembiayaan sukuk yang dilakukan oleh perusahaan penerbangan Emirates Airline juga membuat skema pembiayaan ini semakin dikenal dan dilirik oleh berbagai lembaga di dunia. Mohd Daud Bakar, salah seorang pakar keuangan Islam yang ternama di dunia, memaparkan bahwa pada tahun 2015 Emirates Airline menggunakan sukuk untuk membeli pesawat Airbus A380 terbaru. ${ }^{43}$ Istimewanya lagi kalau sebelumnya aset pendukung sukuk adalah pesawat, kali ini pesawatnya belum ada sama sekali. Hasil dari penjualan sukuk itulah yang akan dijadikan modal untuk membeli empat pesawat baru. Sukuk Emirates Airline ini juga menjadi sukuk pertama yang mendapatkan jaminan daripada pemerintah Inggris dengan total jaminan mencapai US $\$ 913$ juta. Tidak salah kalau kemudian sukuk Emirates Airline ini dianggap membuka babak baru sekaligus menjadi panutan dalam dunia keuangan Islam.

8. Mekanisme Tata Kelola dan Investasi Wakaf Baitul Asyi di Arab Saudi

Selama ini tata kelola wakaf Baitul Asyi dilakukan oleh nazhirnya mengikut regulasi yang berlaku di sana. Setiap pewakaf dapat mengangkat nazhir yang dia inginkan untuk mengelola harta wakaf itu. Nazhir wakaf ini akan dikukuhkan oleh Mahkamah yang juga bertindak mengawasi nazhir wakaf menjalankan tugasnya.

Begitu pula halnya dengan nazhir wakaf Baitul Asyi mulai dari Syeikh Muhamad Shalih bin Abdussalam Asyi selaku nazhir yang ditunjuk oleh Habib Bugak sendiri sampai kepada Syaikh Abdul Lathief Muhammad Baltho dan Prof. Dr. Abdurrahman Abdullah Ba'id Asyi, nazhir yang kesepuluh sekarang ini, perubahan atau penggantian nazhir haruslah dikukuhkan oleh Mahkamah Mekkah.

Dalam menjalankan tugas mengembangkan aset wakaf berupa tanah yang dibeli dari uang kompensasi itu, nazhir wakaf dapat mencari manamana investor yang bersedia untuk melakukan investasi. Mengingat lokasi yang strategis, maka membangun hotel merupakan pilihan terbaik untuk memajukan tanah wakaf Baitul Asyi.

Di antara tanah wakaf Baitul Asyi yang sudah dibangun adalah tempat di mana Hotel Elaf Al Mashaer sekarang ini berada. ${ }^{44}$ Ia terletak di Jalan Ajyad dengan jarak sekitar 300 meter dari Masjid Haram. Satu lagi adalah Hotel Ramada yang juga berada di Jalan Ayjad dengan jarak sekitar 400 meter dari Masjid Haram. ${ }^{45}$ Hotel yang ketiga berada di kawasan Aziziah, di depan Rumah Sakit Alawi Tunisi. Hotel itu memliki kapasitas 250 kamar dan dinamakan Hotel Wakaf Habib Bugak Asyi. ${ }^{46}$ Sayangnya di antara tiga hotel itu, hanya Hotel Elaf Al Mashaer dan Hotel Wakaf

\footnotetext{
${ }^{42} \mathrm{Ibid}$

${ }^{43}$ Untuk mengetahui lebih detail tentang sukuk Emirates Airline ini, lihat, Mohd Daud Bakar, "An Insightful Journey Into Emirates Airline Sukuk", Kuala Lumpur, Amanie Media Sdn. Bhd., 2017, hal. 1-223.

${ }^{44}$ Syaikh Abdul Lathief Muhammad Baltho, Nazir Wakaf Habib Bugak Asyi, wawancara di Mekkah pada 11 April 2019.

${ }^{45} \mathrm{Ibid}$

${ }^{46}$ Ibid
} 
Habib Bugak Asyi saja yang beroperasi karena Hotel Ramada sudah empat tahun tidak diizinkan beroperasi oleh Pemerintah Arab Saudi karena berada di kawasan yang terkena perluasan Masjid Haram. Sampai sekarang kompensasi untuk tanah dan Hotel Ramada belum diberikan. Mungkin setelah semua urusan ganti rugi selesai, nazhir wakaf akan membeli lahan baru dan membangun hotel baru pula dengan menggandeng investor yang mau membangun dan mengelola hotel tersebut.

Hotel Elaf sendiri dibangun oleh nazhir melalui kerjasama dengan investor pengembang. Pada awalnya, menurut Jamaluddin Affan yang menjadi penghubung antara Pemerintah Aceh dengan Nazhir Wakaf Habib Bugak Asyi, pihak nazhir wakaf malah sempat menawarkan kepada pemerintah Aceh untuk menjadi investor atau merekomendasikan investor dari Aceh. Namun, kata Jamaluddin Affan yang selama beberapa tahun terakhir ini turut dipercayakan untuk menyerahkan secara langsung uang kompensasi kepada jamaah haji asal Aceh, setelah menunggu beberapa lama dan tidak ada jawaban yang pasti maka nazhirpun setelah melakukan konsultasi dengan Mahkamah Mekkah memutuskan untuk menerima tawaran yang diberikan oleh investor lain melalui proses tender. ${ }^{47}$ Setelah bangunan hotel siap, investor itu kemudian menyerahkan pengelolaan hotel kepada sebuah perusahaan yang bertindak sebagai manajemen hotel.

Peran nazhir di sini adalah sebagai fasilitator untuk kedua investor baik yang membangun hotel ataupun yang mengelola hotel. ${ }^{48}$ Hotel ini baru akan diserahkan menjadi hak milik penuh Baitul Asyi setelah 23 tahun, sesuai dengan perjanjian awal. Saat ini keuntungan daripada pengelolaan hotel ini dibagi tiga iaitu untuk Baitul Asyi selaku pemilik, investor pengembang dan manajemen pengelola hotel. Satu hal yang perlu digarisbawahi bahwa kesemua proses kerja yang ditempuh oleh nazhir mulai dari mencari investor pengembang dan manajemen pengelola hotel haruslah dilakukan dengan izin daripada Mahkamah Mekkah. Demikian pula mengenai status aset itu tetap menjadi milik Baitul Asyi, tidak boleh beralih kepemilikan. Pernah sebelumnya ada upaya untuk mengalihkan kepemilikan aset itu, namun hal itu tidak berhasil karena Mahkamah Mekkah menganulirnya.

Sedangkan mengenai koordinasi antara nazhir wakaf Baitul Asyi dengan Pemerintah Aceh ketika aset wakaf itu mau dikembangkan ataupun mengenai investor mana yang dijadikan mitra ataupun yang ditolak, maka kalau dilihat dari segi legalitas hal ini sebenarnya tidak perlu dilakukan. Kalaupun nazir wakaf Baitul Asyi mau melakukannya hal ini lebih kepada ikatan moral saja mengingat hasil dari pengeloaan wakaf ini nantinya diperuntukkan untuk jamaah haji asal Aceh.

Melihat kepada kondisi ini maka isu yang berkaitan dengan penolakan keterlibatan BPKH itu harus kita lihat dengan teliti, tidak mencampuradukkan antara menolak investasi dengan menolak untuk dikelola. Kalau menolak untuk dikelola oleh BPKH, maka hal ini tidak relevan karena aset wakaf akan tetap dikelola oleh nazhir wakaf Baitul Asyi yang ditunjuk oleh Mahmakah Mekkah.

Kalau yang ditolak adalah investasi, maka hal ini sedikit rancu karena selama ini nazhir mengembangkan wakaf melalui investasi dari berbagai investor dengan latar belakang yang berlainan pula. Seandainya BPKH mau investasi sudah tentu dapat dilakukan setelah mendapat persetujuan dari nazhir wakaf dan mahkamah karena kedua lembaga itulah yang berhak menerima atau menolak berbagai investor yang mengajukan permohonan kerjasama.

Di sisi lain, investasi juga terbagi dua. Pertama membuat bangunan baru di lokasi yang masih tersedia di sana, kalau ada. Kedua, investasi

\footnotetext{
47 Jamaluddin Affan, penghubung antara Pemerintah Aceh dengan Nazir Wakaf Habib Bugak Asyi, wawancara di Mekkah pada 11 April 2019.

${ }^{48} \mathrm{Ibid}$
} 
terhadap bangunan yang sudah ada. BPKH atau investor lain bisa saja menyewa sebagian atau semua kamar hotel untuk jangka panjang, 15 tahun misalnya. Bayaran ini harus diberikan di muka atau sesuai dengan perjanjian dengan nazhir wakaf. Nah, terhadap aset yang disewa ini, investor bisa saja mengelolanya sendiri ataupun menyerahkannya ke pihak ketiga. Pihak ketiga ini bisa saja manajemen hotel yang sudah mengelola selama ini ataupun pihak yang lain sama sekali.

Bisa jadi juga investasi mengikut setiap jenis barang yang ada di hotel. Misalnya pengadaan AC, tempat tidur, kasur spring bed dan barang-barang interior yang lain. Investor dianggap menyewakan barang ini kepada hotel. Mekanisme bagi hasil tergantung bagaimana perjanjian antara investor dengan manajemen hotel.

Perlu ditegaskan sekali lagi bahwa apapun bentuk investasi, hak milik aset wakaf ini tetap ada pada lembaga wakaf terkait, dalam hal ini Baitul Asyi. Jadi publik tidak perlu khawatir kalau kepemilikan aset akan beralih. Begitu juga halnya kalau BPKH berfikir dapat mengambil alih pengelolaan dan mengalihkan kepemilikan aset wakaf Baitul Asyi, seperti yang dikhawatirkan oleh beberapa pihak di Aceh, ini adalah indikasi mereka masih kurang mengerti mekanisme tata kelola dan investasi wakaf di Arab Saudi. Namun BPKH telah menyatakan bahwa mereka hanya ingin melakukan investasi saja.

9. Mengapa BPKH Perlu Melakukan Investasi di Arab Saudi?

Pada bagian ini penulis ingin memaparkan beberapa alasan mengenai perlunya BPKH melakukan investasi di Arab Saudi baik pada tanah wakaf Baitul Asyi, jika masih ada kesempatan ataupun pada sektor yang lain terkait penyelenggaraan ibadah haji atau umrah.

Pertama, kebijakan pemerintah Arab Saudi yang baru saja memperkenalkan sistem pajak baru kepada pemilik tanah/aset yang tidak membangun aset tersebut dalam tenggang waktu tertentu. ${ }^{49}$ Kebijakan ini bukanlah untuk mengejar setoran pajak, akan tetapi untuk mendorong pembangunan di dalam bidang real estate di sana. Tentunya kebijakan ini akan membuka peluang bagi semua investor, dalam dan luar negeri, untuk bekerja sama dengan pemilik tanah mengembangkannya. Sektor real estate, terutama di Mekkah, merupakan katalis untuk sektor yang lain seperti konstruksi, manufakturing, membuka berbagai peluang pekerjaan bahkan termasuk wisata religi. Oleh karena itu BPKH, sebagai badan yang mengelola dana Keuangan Haji dalam jumlah yang sangat besar, sekitar Rp 120 triliun per Juni 2019, sudah sepantasnya melirik peluang yang ada ini.

Kedua, dengan selesainya berbagai proyek ekspansi perluasan Masjid Haram, maka daya tampung jamaah haji dan umrah akan semakin besar sehingga peluang bisnis dalam berbagai sektor yang menyangkut logistik haji dan umrah pun akan semakin besar. BPKH perlu menangkap peluang baik ini karena bisnis dalam sektor haji dan umrah dewasa ini adalah sektor yang sangat lukratif. ${ }^{50}$

Ketiga, BPKH berpeluang menjadi lembaga keuangan yang diperhitungkan dalam kancah keuangan Islam. Tentu saja salah satu cara yang paling mudah untuk memperkenalkan BPKH adalah dengan melakukan investasi di Mekkah. Investasi dalam jumlah yang besar di Mekkah baik dalam sektor wakaf ataupun sektor yang berhubungan dengan logistik haji dan umrah akan membuat BPKH dengan cepat akan dikenal sebagai salah satu investor yang harus diperhitungkan. Reputasi ini akan memudahkan BPKH dalam melakukan berbagai investasi dalam mengembangkan dan mengelola Keuangan Haji. Investasi di Mekkah adalah pembuka jalan

\footnotetext{
${ }^{49}$ Mohd Daud Bakar, "Shariah is Life: Humanising and Internalising the Shariah”, Kuala Lumpur, Amanie Media Sdn. Bhd., 2018, hal. 60 .

${ }^{50}$ Untuk informasi lebih detil mengenai perkembangan dan peluang sektor perhotelan di Mekkah, baca, "GCC Hospitality Industry", Alpen Capital, Juli 2018. Baca juga, "Makkah: A City within A City”, Jones Lang LaSalle IP, Inc., Desember 2016. Baca juga, "Makkah Real Estate Market: Overview", Jones Lang LaSalle IP, Inc., 2017.
} 
bagi BPKH menjadi 'game changer' dan 'trend setter' pengelolaan Keuangan Haji. Saat Tabung Haji Malaysia sebagai lembaga tabung haji yang terpandang selama ini sedang didera berbagai masalah, inilah saatnya BPKH berkembang secara eksponensial.

Keempat, dengan melakukan investasi pada sektor wakaf di Arab Saudi, BPKH akan memperoleh pengalaman yang sangat berharga tentang bagaimana melakukan tata kelola wakaf yang efektif. Mendapatkan pengalaman langsung mengelola aset wakaf akan membawa dampak positif bagi perkembangan wakaf di tanah air. Betapa tidak aset wakaf di Indonesia adalah aset wakaf yang terbesar di dunia, namun secara keseluruhan pengembangannya masih belum begitu menggembirakan dan masih belum memberikan impak secara ekonomi untuk masyarakat di Indonesia. Pengalaman langsung yang BPKH dapatkan nantinya akan dapat direplikasi pada sektor wakaf di tanah air. Di sisi lain, dengan investasi wakaf di sana, bisa jadi BPKH akan mampu membuka dan menyibak tabir banyaknya aset wakaf Indonesia di Arab Saudi yang sudah tidak diketahui lagi rimbanya. Oleh karena itu, peluang yang terbuka untuk berinvestasi dalam tanah wakaf di Mekkah harus dimanfaatkan oleh BPKH dengan sebaik-baiknya.

Kelima, BPKH sebagai lembaga yang baru haruslah berani memiliki mimpi besar untuk menjadi lembaga paling hebat dalam keuangan Islam. Dengan segala potensi yang dimiliki mulai dari besarnya dana yang dikelola, banyaknya penduduk Islam di Indonesia, sudah sepantaslah BPKH mampu memainkan peranan penting di dunia keuangan Islam. Kalau penerbangan Emirates Airline mampu membawa perubahan besar dalam dunia keuangan Islam dengan inovasi produk sukuk mereka, sudah sepantasnyalah BPKH mampu melakukan hal serupa. Tentunya langkah pertama adalah dengan berani melakukan investasi langsung di Mekkah.

\section{Kesimpulan dan Rekomendasi}

BPKH harus melihat reaksi negatif yang ditunjukkan oleh publik sebagai tantangan bagi mereka untuk menunjukkan kinerja terbaik dalam mengelola dana Keuangan Haji terutama dalam mengembangkan aset wakaf. BPKH juga harus melakukan sinergi dengan pemangku kepentingan wakaf untuk memberikan pencerahan kepada publik mengenai mekanisme investasi wakaf baik di dalam atau di luar negeri untuk menghindari polemik berkepanjangan yang banyak menguras energi yang disebabkan oleh kekurangfahaman semua pemangku kepentingan mengenai tata kelola dan mekanisme investasi wakaf.

Akhirnya, kita berharap polemik rencana investasi wakaf oleh BPKH dapat menjadi titik tolak untuk mengembangkan berbagai aset wakaf baik di dalam ataupun di luar negeri sehingga dapat memberikan keuntungan yang lumayan atas dana Keuangan Haji yang dikelola dan pada saat yang sama juga memainkan peranan untuk membiayai usaha-usaha memajukan aset wakaf yang selama ini terlantar. Kalau ini bisa terwujud, maka BPKH akan dapat mengikuti jejak keberhasilan yang pernah dicapai oleh Tabung Haji Malaysia dalam mengelola dana haji sekaligus menjadi pioner dalam bidang pembangunan dan pengembangan wakaf, khususnya di Indonesia.

\section{Daftar Pustaka}

"Abdullah Puteh Perjelas Status WakafBaitul Asyi", http://aceh.tribunnews.com/2018/03/14/ abdullah-puteh-perjelas-status-wakaf-baitulasyi? page $=$ all, diakses pada 29 November 2018.

"Alasan BPKH Incar Investasi Tanah Wakaf di Arab Saudi”, https://www.cnnindonesia.com/ ekonomi/20180315165636-78-283318/ alasan-bpkh-incar-investasi-tanah-wakafaceh-di-arab-saudi, diakses pada 30 November 2018.

Alwi Rahman, "Optimalisasi Investasi Dana Biaya Penyelenggaraan Ibadah Haji Tahun 2006 oleh Ditjen Penyelenggaraan Haji 
dan Umrah Kementerian Agama Republik Indonesia”, (Skripsi, Universitas Islam Negeri Syarif Hidayatullah Jakarta, 2017).

Al Yasa' Abubakar, Mengenal Wakaf Habib Bugak Asyi (Baitul Asyi Mekah), Buletin Narit Geutanyo, Jilid 3, No. 6, 2009, Kg. Aceh Yan, Kedah, Malaysia, Ikatan Masyarakat Aceh Malaysia (IMAM), 2009.

Al Yasa' Abubakar, "Baitul Asyi Wakaf Habib Bugak di Mekkah”, http://aceh.tribunnews. com/2018/03/19/baitul-asyi-wakaf-habibbugak-di-mekkah?page=all, diakses 30 November 2018.

Amelia Fauzia, Filantropi Islam: Sejarah Kontestasi Masyarakat Sipil dan Negara di Indonesia”, Yogyakarta: Gading Publishing, 2016.

"Anggota DPR Tolak Niat BPKH Kelola Tanah Wakaf Rakyat Aceh", https://www. republika.co.id/berita/jurnal-haji/beritajurnal-haji/18/03/10/p5dfmy396-anggotadpr-tolak-niat-bpkh-kelola-tanah-wakafrakyat-aceh, diakses pada 29 November 2018.

Anwar Fuadi Salam, Menelusuri Bayt al-Asy di Tanah Suci (Bagian 2), http://bwi.or.id/ index.php/in/publikasi/artikel/540. menelusuri-bayt-al-asy-di-tanah-sucibagian-2-html, diakses pada 29 November 2018.

"BPKH akan Investasi di atas Tanah Wakaf Aceh di Arab Saudi”, https://www.republika.co.id/ berita/http://www.republika.co.id/berita/ jurnal-haji/berita-jurnal-haji/18/03/09/ p5b9kq396-bpkh-akan-investasi-di-atastanah-wakaf-aceh-di-arab-saudi, diakses 29 November 2018.

"BPKH Jajaki Kerja Sama Investasi Hotel di Tanah Suci", https://www.republika.co.id/berita/ jurnal-haji/berita-jurnal-haji/18/03/10/ p5debj396-bpkh-jajaki-kerja-sama-investasihotel-di-tanah-suci, diakses pada 30 November 2018.

Fahmi M. Nasir, "Investasi Wakaf", http://aceh. tribunnews.com/2018/03/22/investasi- wakaf?page $=$ all, diakses pada 30 November 2018.

Fahmi M. Nasir dan Hidayatul Ihsan, "Pushing boundaries of waqf financing in Indonesia", http://www.thejakartapost.com/academia/ 2018/02/14/pushing-boundaries-of-waqffinancing-in-indonesia.html, diakses pada 30 November 2018.

"Haji Uma Surati Nazir Wakaf Aceh di Arab Saudi, Tolak Rencana Investasi Indonesia di Baitul Asyi”, http://aceh.tribunnews. com/2018/03/13/haji-uma-surati-nazirwakaf-aceh-di-arab-saudi-tolak-rencanainvestasi-indonesia-di-baitul-asyi, diakses pada 29 November 2018.

Hydzulkifli Hashim Omar dan Asmak Ab Rahman, "Pembiayaan Pembangunan Harta Wakaf Menggunakan Sukuk", Kuala Lumpur, Penerbit Universiti Malaya, 2015.

"Ini Penegasan Pemerintah Aceh Terkait Rencana Investasi BPKH di Tanah WakafBaitul Asyi”, http://aceh.tribunnews.com/2018/03/14/ ini-penegasan-pemerintah-aceh-terkaitrencana-investasi-bpkh-di-tanah-wakafbaitul-asy, diakses pada 29 November 2018.

Izrin Muaz Md Adnan, "A History of the Acheen Street Malay Enclave from Oral History Accounts", Journal of the Malaysian Branch of the Royal Asiatic Society, vol. 85, Part 1, No. 302 June 2012.

Jamaluddin Affan, penghubung antara Pemerintah Aceh dengan Nazir Wakaf Habib Bugak Asyi, wawancara di Mekkah pada 11 April 2019.

Laporan, "GCC Hospitality Industry", Alpen Capital, Juli 2018.

Laporan, "Makkah: A City within A City", Jones Lang LaSalle IP, Inc., Desember 2016.

Laporan, "Makkah Real Estate Market: Overview", Jones Lang LaSalle IP, Inc., 2017.

"Mahasiswa Gelar Aksi Tolak Rencana Investasi BPKH di Baitul Asyi”, http://portalsatu. $\mathrm{com} / \mathrm{read} /$ news/mahasiswa-gelar-aksi-tolak- 
rencana-investasi-bpkh-di-baitul-asyi-41472, diakses pada 29 November 2018.

Mohd Daud Bakar, "An Insightful Journey Into Emirates Airline Sukuk", Kuala Lumpur, Amanie Media Sdn. Bhd. 2017.

Mohd Daud Bakar, "Shariah is Life: Humanising and Internalising the Shariah", Kuala Lumpur, Amanie Media Sdn. Bhd. 2018.

Muhammad Arief Rahman, "Proses Pembentukan Badan Pengelola Keuangan Haji: Sebuah Kajian Kebijakan Publik" (Skripsi, Universitas Islam Negeri Syarif Hidayatullah Jakarta, 2016).

M. Imam Syairozi dan Septyan Budy Cahya, "Sukuk Al Intifa'a: Integrasi Sukuk dan Wakaf dalam Meningkatkan Produktifitas Sektor Wakaf Pendorong Investasi Pada Pasar Modal Syariah, Jurnal Penelitian Ilmu Manajemen”, Vol II, No. 2, Juni 2016.

"Pengelolaan Dana Haji dan Rencana Strategis BPKH 2018-2022", http://bpkh.go.id/halvisi-dan-misi-bpkh.html, diakses pada 29 November 2018.

Peraturan Pemerintah Republik Indonesia Nomor 5 Tahun 2018 Tentang Pelaksanaan Undang-Undang Nomor 34 Tahun 2014 Tentang Pengelolaan Keuangan Haji.

Peraturan Presiden Republik Indonesia Nomor 110 Tahun 2017 Tentang Badan Pengelola Keuangan Haji.

Securities Commission Malaysia, "Waqf Assets: Development, Governance and The Role of Islamic Capital Market", Kuala Lumpur, Securities Commission Malaysia, 2014.

Sharifah binti Ismail, "The Hajj From Malaysia: Its History, Management and Impact on The Malay Society, 1975-2005” (Disertasi Doktoral, International Islamic University Malaysia, December 2016).
Snouck Hurgronje, C. "Mecca in the Latter Part of the 19th Century, Daily Life, Customs and Learning of The Moslims of the EastIndian Archipelago", diterjemahkan oleh J.H. Monahan, Leiden: Brill, 1931.

"Soal Tanah Wakaf, Partai Aceh Tolak Rencana BPKH”, https://www.republika.co.id/ berita/jurnal-haji/berita-jurnal-haji/18/03/ 11/p5f1jw396-soal-tanah-wakaf-partaiaceh-tolak-rencana-bpkh, diakses pada 29 November 2018.

Syaikh Abdul Lathief Muhammad Baltho, Nazir Wakaf Habib Bugak Asyi, wawancara di Mekkah pada 11 April 2019.

"Tabung Haji lodges police reports against former chairman, CEOs, and senior management", http://www.theedgemarkets.com/ article/tabung-haji-lodges-police-reportsagainst-former-chairman-ceos-and-seniormanagement, diakses pada 30 November 2018.

“Temui JK, BPKH Lapor Rencana Pengelolaan Tanah Wakaf di Makah", https://news. detik.com/berita/3907326/temui-jk-bpkhlapor-rencana-pengelolaan-tanah-wakaf-dimakah, diakses pada 29 November 2018.

Tuti A. Najib dan Ridwan al-Makassary (ed.), "Wakaf, Tuhan dan Agenda Kemanusiaan", Jakarta, Centre for Study of Religion and Culture (CSRC) Universitas Islam Negeri (UIN) Syarif Hidayatullah, 2006.

Undang-Undang Republik Indonesia Nomor 34 Tahun 2014 Tentang Pengelolaan Haji. 